\title{
Reimplantation of an avulsed tooth after five hours of storage in milk: One-year follow-up case report
}

\author{
Pelin Tufenkci*1, Fatma Canbolat ${ }^{2}$, Berkan Celikten ${ }^{2}$, Semra Sevimay ${ }^{2}$ \\ ${ }^{1}$ Department of Endodontics, Faculty of Dentistry, University of Mustafa Kemal, Hatay, Turkey \\ ${ }^{2}$ Department of Endodontics, Faculty of Dentistry, University of Ankara, Ankara, Turkey
}

Received: September 13, 2017

DOI: $10.5430 /$ crim.v4n $4 \mathrm{p} 48$
Accepted: November 6, $2017 \quad$ Online Published: November 14, 2017

URL: https://doi.org/10.5430/crim.v4n4p48

\begin{abstract}
Dental avulsion is the complete displacement of a tooth from the alveolar socket due to trauma. Reimplantation is the procedure by which an avulsed tooth is replaced. The prognosis of reimplantation depends on several factors, the most important of which are the length of time that elapses between the trauma and reimplantation and how the tooth is stored. The most preferable management procedure for an avulsion is immediate reimplantation within 20-30 min after injury or preservation in an appropriate storage medium until the procedure. If the tooth cannot be immediately replanted, it should be stored in Hank's Balanced Salt Solution, milk, saliva, or saline solution. Milk is readily available and can protect periodontal ligament cells. In this case report, a 30-year-old male patient suffered a sports injury that resulted in avulsion of the right maxillary incisor. The avulsed tooth was stored in milk for $5 \mathrm{~h}$ from avulsion until reimplantation. This case report details reimplantation of an avulsed tooth.
\end{abstract}

Key Words: Avulsion, Dental injury, Delayed reimplantation

\section{INTRODUCTION}

Sports, auto, and bicycle accidents and violent trauma can lead to dental injuries that cause cosmetic and functional deficits. All forms of traumatic dental injuries require immediate treatment. However, avulsed teeth lead to bacterial contamination both intraorally and extraorally, so have specific treatment considerations, in contrast to other dental traumatic injuries. Although avulsion can affect patients of any age, it is more prevalent in young patients due to undeveloped bones and periodontium. ${ }^{[1]}$

Extraoral time and a suitable storage medium are the main factors that affect the prognosis of avulsed teeth. Anderson recommended that avulsed teeth be reimplanted within $5 \mathrm{~min}$ for the best prognosis. ${ }^{[2]}$ With increased extraoral time, the incidence of attachment damage, pulp necrosis, and small localized cemental damage increases, which can lead to eventual external and internal root resorption. ${ }^{[3-5]}$ Previous studies have shown that reimplantation within 20-30 min of avulsion and storage in a suitable storage medium (milk, saline, saliva, or Hank's Balanced Salt Solution) contribute to a better prognosis. ${ }^{[6,7]}$ This case report describes management of an avulsed right central incisor, which was reimplanted $5 \mathrm{~h}$ after the injury and stored in milk prior to the procedure.

\section{CaSe presentation}

A 30-year-old male patient presented to the Department of Endodontics at Ankara University for an avulsed tooth and lip laceration due to a sports accident approximately $5 \mathrm{~h}$ pre-

\footnotetext{
${ }^{*}$ Correspondence: Pelin Tufenkci; Email: ptufenkci@mku.edu.tr; Address: Department of Endodontics, Faculty of Dentistry, University of Mustafa Kemal, Hatay, Turkey.
} 
viously. The patient found the avulsed but otherwise intact tooth, washed the soil off of it, and stored it in milk. Extraoral and intraoral physical examination revealed swelling and edematous lips as well as a missing right maxillary incisor.
Clinical and radiographic examination of the tooth socket revealed no fractures of the alveolar bone (see Figure 1).
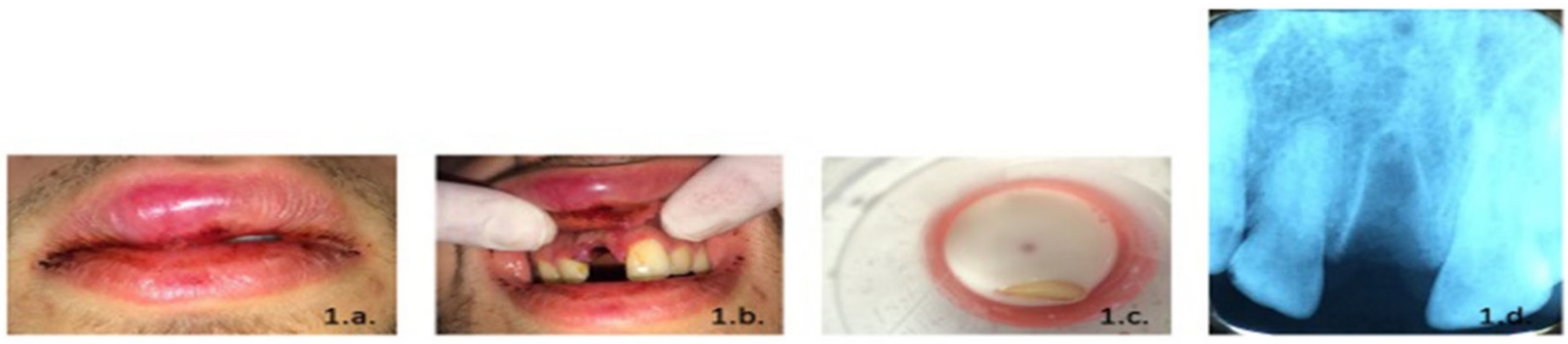

Figure 1. (a) Extraoral examination revealed swelling and edema of the upper lips. (b) The patient stored the tooth in milk for $5 \mathrm{~h}$ between the trauma and reimplantation. (c) Intraoral examination of the tooth socket. (d) Radiographic evaluation of the alveolar bone showed no fractures.

First, the tooth was removed from the milk, its crown was stabilized with a presell and the tooth surface was washed with saline. After administration of local anesthesia, any coagulum, granulation or pathological tissues was gently curetted from the socket and the socket was irrigated with saline solution. The right maxillary central incisor was reimplanted into the socket manually. Dental occlusion was checked to confirm that there was no premature contact and then the maxillary arcade was splinted from canine-to-canine with a stainless-steel wire and composite (see Figures 2 and 3).
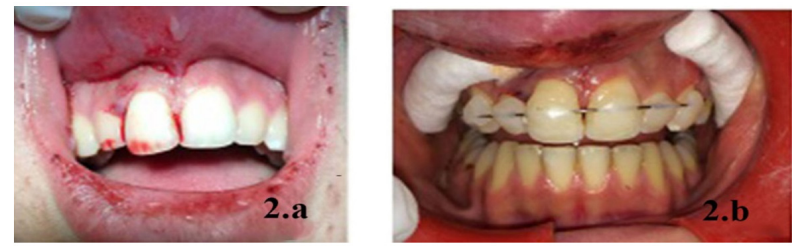

Figure 2. (a) The maxillary right central incisor was reimplanted into the socket by hand. (b) The maxillary right central incisor was splinted from canine-to-canine.

The endodontic access cavity was prepared on this visit and the necrotic pulp was removed from the root canal. The working length was determined using an apex locator (Morita, Kyoto, Japan) and radiography. The root canal was prepared with \#15-50H files. During the endodontic treatment, the root canal was irrigated with $2 \mathrm{ml}$ of $5.25 \%$ sodium hypochlorite $(\mathrm{NaOCl})$ after the use of each file. Finally, the site was rinsed with $5 \mathrm{ml}$ of $5.25 \% \mathrm{NaOCl}, 17 \%$ ethylenediaminetetraacetic acid (EDTA) for 1 minute, and $5 \mathrm{ml}$ of distilled water, and dried with paper points. Calcium hydroxide paste was applied to the root canal site and the cavity was temporarily filled with Cavit-G (3M Espe, USA). The patient was instructed to maintain good oral hygiene, follow a soft diet, and avoid mastication in that area. In addition, antibiotics (amoxicillin and clavulanic acid) were prescribed for one week and $0.2 \%$ chlorhexidine mouthwash was recommended. The patient was scheduled for follow-up after one week.

After one week, the splint was removed and the calcium hydroxide was reapplied. The patient was scheduled for follow-up two weeks later.
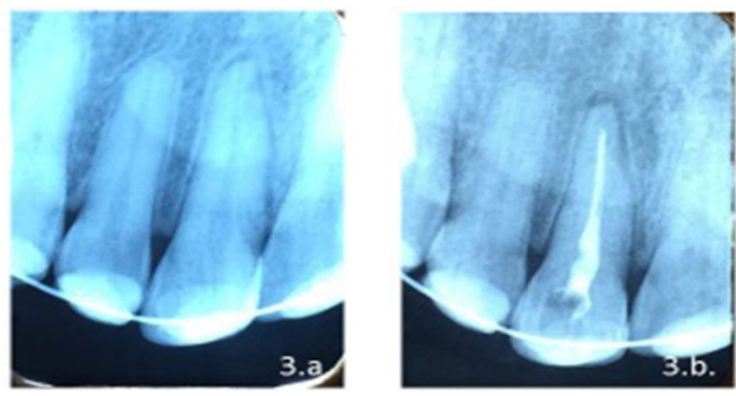

Figure 3. (a) A periapical radiograph was taken to confirm the position of reimplanted tooth in the socket with semi-rigid splint before endodontic treatment. (b) Root canal treatment with gutta-percha before removal of the splint three weeks after reimplantation.

After two weeks, the tooth appeared to be clinically and radiographically normal. \#45h files and $5 \mathrm{ml}$ of $5.25 \%$ $\mathrm{NaOCl}$ were used for removing of the calcium hydroxide paste. Then, the root canal was irrigated with $5 \mathrm{ml}$ of $5.25 \%$ $\mathrm{NaOCl}, 17 \%$ EDTA for 1 minute and $5 \mathrm{ml}$ of distilled water, and dried with paper points. The root canal was filled with AH Plus and gutta-percha using a lateral compaction technique (see Figure 3). The permanent filling was completed using a resin composite. The patient returned for follow-up every six months (see Figure 4). 

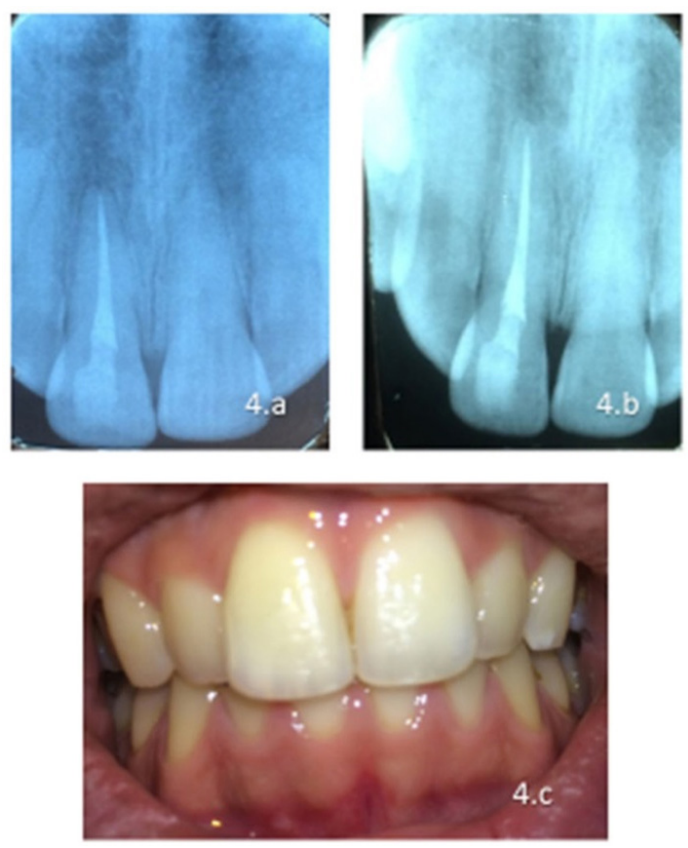

Figure 4. Radiographic evaluation of the tooth at (a) six months and (b) one year. (c) Clinical evaluation at one-year follow-up.

\section{Discussion}

Tooth avulsion, or complete displacement of the tooth from its socket, eventually causes damage to the periodontal ligament, alveolar bone, cementum, gingiva, and dental pulp. Complications of avulsed teeth include pulp necrosis, internal/external root resorption, ankylosis, and loss of the periodontal ligament. The incidence of complications depends on several factors, namely, transportation/storage of the teeth, the time that elapses between avulsion and reimplantation, and splinting technique and time. ${ }^{[8]}$

For cases requiring reimplantation, the prognosis is best if the tooth can be replanted immediately after the avulsion. If the tooth cannot be immediately replanted, it should be stored in Hank's Balanced Salt Solution, milk, saliva, or saline. Milk is readily available and can preserve the periodontal ligament cells.

The patient in this case knew to use milk as a storage medium, which was used for $5 \mathrm{~h}$ prior to reimplantation. Milk is a good choice due to its osmolarity and $\mathrm{pH}$ and has been shown to preserve periodontal ligament cells for up to $8 \mathrm{~h} .{ }^{[9]}$ Trope et al. stated that Hank's Balanced Salt Solution is considered the best storage medium, but milk and physiological saline are acceptable as convenient alternatives. ${ }^{[10]}$

After the splint is placed, preoperative radiographs should be taken to check the positioning of the tooth for the future treat- ment plan and follow-up. The tooth should be fixed in the best acceptable position to prevent traumatic occlusion. The avulsed tooth must be kept in place for one week to allow formation of the periodontal support. For this reason, the splint should be removed after 7-10 days. However, if the avulsion is accompanied by alveolar fractures, the tooth should be splinted for 4-8 weeks. ${ }^{[6]}$ In the current case, the missing tooth was fitted into the alveolar socket with finger pressure and its position was confirmed by radiography. Moreover, the premature contacts were removed from the tooth and were adjusted to align with the lower tooth. In addition, the splint time was only seven days since there were no alveolar fractures.

The tooth was reimplanted into the socket and semi-rigid splinting was performed using composite resin and stainless steel from canine to canine. Semi-rigid splints are preferred for avulsion injuries due to the root resorption that rigid splints have demonstrated in both mature and immature teeth. ${ }^{[1-13]}$ Moreover, acid-etch bonded splints are easily tolerated by the patient and allow good oral hygiene. ${ }^{[14]}$

Hecova et al. reported that pulp necrosis is the most common complication for avulsed teeth and stated that its incidence is $100 \%$ for closed root apices and $76.5 \%$ for open root apices after avulsion. In this case, the tooth was mature with closed root apices and the immediate applied of root canal treatment was thought to be appropriate. ${ }^{[12]}$

Calcium hydroxide has antibacterial effects and also creates a more alkaline $\mathrm{pH}$. Alkaline $\mathrm{pH}$ affected to resorptive cells and promoted hard tissue formation. ${ }^{[1,15,16]}$ However, because of the necrotizing effect of the cells that are attempting to populate the damaged root surface, calcium hydroxide should not be replaced too often. ${ }^{[13]}$ In the present case, calcium hydroxide was placed in the canal only twice, which is ideal.

Andreasen \& Hjerting-Hansen were the first to classify the external resorptive processes associated with reimplanted teeth. ${ }^{[17]}$ Based on the radiographic findings and histological samples from human cases, three categories were proposed: surface resorption, replacement resorption (ankylosis), and inflammatory resorption. In this case, the patient was called for routine follow-up at 1, 3, 6, and 12 months.

In conclusion, radiological and clinical examination revealed that the reimplanted tooth had no root resorption and had a healthy lamina dura after one year. The patient is still being followed up routinely.

\section{CONFLiCTS OF INTEREST Disclosure}

The authors have declared no conflicts of interest. 


\section{REFERENCES}

[1] Sharma NK, Duggal MS. Replantation in general dental practice. British Dental Journal. 1994 Feb; 176(4): 147-51. PMid:8123319 https://doi.org/10.1038/sj . bdj . 4808392

[2] Andreasen JO. Effect of extra-alveolar period and storage media upon periodontal and pulpal healing after replantation of mature permanent incisors in monkeys. International Journal of Oral Surgery. 1981 Feb; 10(1): 43-53. https ://doi .org/10.1016/S0300-978 5 (81) $80007-5$

[3] Andreasen JO, Borum MK, Jacobsen HL, et al. Replantation of 400 avulsed permanent incisors. 4. Factors related to periodontal ligament healing. Endodontics \& Dental Traumatology. 1995 Apr; 11(2): 76-89. PMid:7641622 https : //doi .org/10.1111/j.1600-965 7.1995.tb00464.x

[4] Hiltz J, Trope M. Vitality of human lip fibroblasts in milk, Hanks balanced salt solution and Viaspan storage media. Endodontics \& Dental Traumatology. 1991 Apr; 7(2): 69-72. PMid:1782897 https://doi.org/10.1111/j.1600-9657.1991.tb00187.x

[5] Blomlöf L, Lindskog S, Andersson L, et al. Storage of experimentally avulsed teeth in milk prior to replantation. Journal of Dental Research. 1983 Aug; 62(8): 912-6. PMid:6575041 https : //doi.org/10.1177/00220345830620081301

[6] Andreasen JO, Borum MK, Jacobsen HL, et al. Replantation of 400 avulsed permanent incisors. 1. Diagnosis of healing complications. Endodontics \& Dental Traumatology. 1995 Apr; 11(2): 51-8. PMid:7641619 https://doi.org/10.1111/j.1600-965 7.1995.tb00461.x

[7] Barrett EJ, Kenny DJ. Avulsed permanent teeth: a review of the literature and treatment guidelines. Endodontics \& Dental Traumatology. 1997 Aug; 13(4): 153-63. PMid:9550040 https ://doi.org/10.1 111/j.1600-9657.1997.tb00031.x

[8] Lin S, Pilosof N, Karawani M, et al. Occurrence and timing of complications following traumatic dental injuries: A retrospective study in a dental trauma department. Journal of Clinical and Experimental Dentistry. 2016 Oct 1; 8(4): e429-e436. https : //doi .org/10.4 $317 /$ jced. 53022

[9] Andersson L, Andreasen JO, Day P, et al. International Association of Dental Traumatology guidelines for the management of traumatic dental injuries: 2. Avulsion of permanent teeth. Dental
Traumatology. 2012 Apr; 28(2): 88-96. PMid:22409417 https: //doi.org/10.1111/j.1600-9657.2012.01125.x

[10] Trope M. Clinical management of the avulsed tooth: present strategies and future directions. Dental Traumatology. 2002 Feb; 18(1): 1-11. PMid:11841460 https ://doi.org/10.1046/j.1600-446 9.2001.00001.x

[11] Sjögren U, Figdor D, Spangberg L, et al. The antimicrobial effect of calcium hydroxide as a short-term intracanal dressing. International Endodontic Journal. 1991 May; 24(3): 119-25. PMid:1778624 https ://doi.org/10.1111/j.1365-2591.1991.tb00117.x

[12] Hecova H, Tzigkounakis V, Merglova V, et al. A retrospective study of 889 injured permanent teeth. Dent Traumatology. 2010 Dec; 26(6): 466-75. PMid:20946344 https://doi .org/10.1111/j.1600-9 $657.2010 .00924 . x$

[13] Lengheden A, Blomlöf L, Lindskog S. Effect of delayed calcium hydroxide treatment on periodontal healing in contaminated replanted teeth. Scandinavian Journal of Dental Research. 1991 Apr; 99(2): 147-53. https://doi.org/10.1111/j.1600-0722.19 91.tb01877.x

[14] Filippi A, Von Arx T, Lussi A. Comfort and discomfort of dental trauma splints- a comparison of a new device (TTS) with three commonly used splinting techniques. Dental Traumatology. 2002 Oct; 18(5): 275-80. PMid:12427202 https://doi.org/10.103 4/j.1600-9657.2002.00121.x

[15] Bystrom A, Claesson R, Sundqvist G. The antibacterial effect of camphorated paramonochlorophenol, camphorated phenol and calcium hydroxide in the treatment of infected root canals. Endodontics \& Dental Traumatology. 1985 Oct; 1(5): 170-5. PMid:3865763 https://doi.org/10.1111/j.1600-9657.1985.tb00652.x

[16] Tronstad L, Andreasen JO, Hasselgren G, et al. pH changes in dental tissues after root canal filling with calcium hydroxide. Journal of Endodontics. 1981 Jan; 7(1): 17-21. https://doi.org/10.1016/ S0099-2399 (81) 80262-2

[17] Andreasen JO, Hjorting-Hansen E. Replantation of teeth. I. Radiographic and clinical study of 110 human teeth replanted after accidental loss. Acta Odontologica Scandinavica. 1966 Nov; 24(3): 263 86. PMid:5225449 https://doi.org/10.3109/000163566090 28222 